学術論文

\title{
磁性流体を用いた同調液柱管ダンパーにおける液柱減衰力の変化が 制振力に及ぼす影響
}

\section{The effect to the damping performance of magnetic fluid tuned liquid column damper induced by various damping coefficient of liquid column}

\author{
碇 一睡 ${ }^{* 1}$ (学生員), 近藤 真也 ${ }^{* 1}$, 澤田 達男 ${ }^{* 1}$ (正員)
}

Kazuki IKARI(Stu. Mem.), Sinya KONDO, Tatsuo SAWADA(Mem.)

\begin{abstract}
Magnetic fluid tuned liquid column damper (MF-TLCD) is a kind of semi-active damper that uses magnetic fluid as its working fluid. An MF-TLCD alters the natural frequency of the magnetic fluid column that forms the resident liquid inside the MF-TLCD by applying a magnetic field. We quantitatively investigated the damping coefficient generated by the flow of magnetic fluid, which is strongly related to the damping performance. Three kind of U-pipes that have each different shape ((1) conventional (2) equipped with an orifice (3) curved fluently) were prepared and single-degree-of-freedom oscillation was performed with each those pipes. Finally, we discussed the effect to the damping performance of MF-TLCD induced by various damping coefficient subjected to magnetic field and configurations of those U-pipes.
\end{abstract}

Keywords: magnetic fluid, tuned liquid column damper, damping coefficient, magnetic field, U-pipe

\section{1 緒言}

$\mathrm{U}$ 字管内の夜体摇動は，船舶の横摇れ防止のための 制振装置として従来から用いられており，これはアン チローリングタンク(ART, Anti Rolling Tank)[1]と呼ば れている。この ART と作動原理がほぼ同じで, その制 振対象を船舶から構造物一変更したものが同調液柱管 ダンパー(TLCD, Tuned Liquid Column Damper)[2]であ る。TLCD は, U 字管内の液体振動で生じる水平方向 の慣性力を制振力として利用する制振装置で，外部か らのエネルギーを必要としないパッシブダンパーであ る。TLCD の特徴としては, 固有振動数が液柱長のみ で変化させられること, 液柱運動が管軸方向に沿った 一自由度運動として容易に解析できることが挙げられ る。しかし, 他のパッシブダンパーと同様に同調の誤 差に敏感で制振効果が発揮できる周波数帯が狭いこと や，U字管中央に取り付けたオリフィスの水頭損失か ら生じる減衰が非線形なため, 制振性能が振幅に依存 するなどの久点が存在する。

このような久点を改善するために TLCD のセミアク ティブ化が図られており，それらはほとんどが液柱減 衰力を制御する方式である。減衰力を制御する方法と

連絡先：澤田＼cjkstart達男, 广223-8522 横浜市港北区日吉 3-14-1, 慶應義塾大学理工学部機械工学科,

e-mail: sawada@mech.keio.jp

${ }^{* 1}$ 慶應義塾大学
しては，バルブ調節によってオリフィスの開口率を可 変にする方法 $[3,4]$ と作動流体に MR 流体を用いて磁場 印加による粘性力増加を利用する方法[5]の二種類が 提案されている。

本研究では, 作動流体に磁性流体を用いた TLCD (以 後, MF-TLCD と略記) を提案している。MF-TLCD は, 電磁石による定常磁場を利用して磁性流体に磁気力を 与え, 減衰ではなく磁性流体液柱の復元力を変化させ ることで固有振動数を制御可能としたセミアクティブ ダンパーである。よって, 印加磁場によって常に最適 な同調比を満たすことができ，高い制振効果を広周波 数帯で発揮可能である。小山田ら[6]は MF-TLCD の固 有振動数変化を線形解析によって明らかにすると共に, 構造物-MF-TLCD 二自由度強制振動実験を行うことに よって，従来の TLCD よりも MF-TLCD の制振効果が 高いことを実証した。

本研究では, U字管形状と磁場印加条件が MF-TLCD の液柱減衰比をどの程度変化させるかを定量的に求め, その減衰比変化が制振力に及ぼす影響を考察すること を目的とした。U 字管形状としては (1)従来形状(2)才 リフィス付加(3)曲がり管を緩やかにした U 字管の三 種類を用意した。これらU 字管を用いて一自由度磁性 流体液柱強制振動実験を行い，液面振幅周波数応答を 測定し，共振点振幅から減衰比を算出した。そして， 減衰比の值をそれぞれのU字管形状にて比較を行った。 


\section{2 理論}

\section{1 定常磁場下での一自由度磁性流体液柱強制振動}

Fig. 1のようにU 字管内の磁性流体液柱の一自由度 強制振動を考える。磁性流体は非圧縮とし，スロッシ ングによる液面動摇は無視する。また，U字管内に働 く磁場強さは半径方向に依存しないものとする。磁性 流体液柱に働く磁気体積力項を $F_{m}$ とすれば, 液面変位 $x_{m}$ の運動方程式は以下のように表せる。

$$
\rho A l \ddot{x}_{m}+c_{m} \dot{x}_{m}+2 \rho A g x_{m}-F_{m}=-\rho A b \ddot{y}
$$

ここで, $y$ は外部加振による $\mathrm{U}$ 字管の水平方向変位, $\rho$ は磁性流体密度, $A$ は液柱断面積, $l$ は液柱長さ, $b$ は 液柱の水平方向長さ， $c_{m}$ は管内流れが層流だと仮定し た場合の減衰係数， $g$ は重力加速度である。また，磁 気体積力項 $F_{m}$ は以下のように表せる[7]。

$$
F_{m}=-\frac{A \mu_{0} \chi}{2}\left[\left\{H\left(x_{m}\right)\right\}^{2}-\left\{H\left(-x_{m}\right)\right\}^{2}\right]
$$

$$
H\left(x_{m}\right)=\frac{N I}{2 L}\left[\frac{x_{m}-h+L / 2}{\sqrt{\left(x_{m}-h+L / 2\right)^{2}+r^{2}}}-\frac{x_{m}-h-L / 2}{\sqrt{\left(x_{m}-h-L / 2\right)^{2}+r^{2}}}\right]
$$

ここで， $\mu_{0}$ は真空の透磁率， $\chi$ は磁性流体の磁化率， $h$ は一つの実験系における電磁石位置で, 静水面から電 磁石中心までの距離で表される。ただし, 静水面より 上側(+)か下側(-)かでそれぞれ符号を持つ。 $h$ は両側の 電磁石で同じ值に設定され，対称な定常磁場が U 字管 内に働いている。更に，Hはソレノイドが作る磁場と

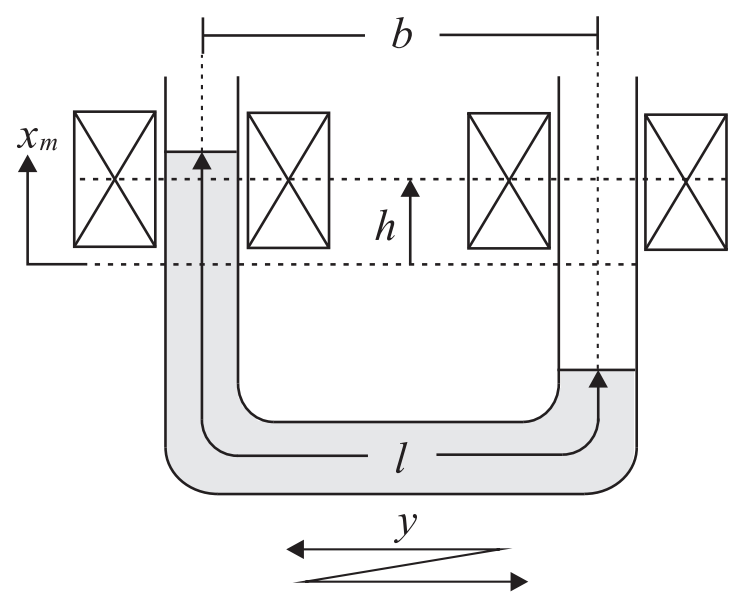

Fig. 1 Analytical model of MF-TLCD.
した時の磁場強さであり, 電磁石巻数 $N$, 電磁石長さ

$L$, 電磁石内径 $r$, 供給電流 $I$ によって求められる。

\section{2 磁気体積力項の線形化による固有振動数解析}

式(2)で示したように，磁気体積力項 $F_{m}$ はそのまま では非線形なため解析が難しい。そこで，液面変位 $x_{m}$ を微小と仮定してやることで $F_{m}$ の線形化を行う。その 結果， $F_{m}$ は以下のように置き換えられる。

$$
F_{m} \approx-2 A \mu_{0} \chi H(0) \cdot H^{\prime}(0) \cdot x_{m}
$$

$H^{\prime}$ は磁場強さ $H$ を変位 $z$ で微分した時の磁場勾配を 表している。更に，この線形化によって磁性流体液柱 の固有振動数 $f_{n}$ が以下のように求められる。

$$
\begin{gathered}
f_{n}=\frac{1}{2 \pi} \sqrt{\frac{2 g^{*}}{l}} \\
g^{*}=g-\frac{\mu_{0} \chi H(0) \cdot H^{\prime}(0)}{\rho}
\end{gathered}
$$

ここで， $g^{*}$ は定常磁場下において磁性流体液柱に働く 見かけの重力加速度である。式(6)より，磁場勾配 $H^{\prime}(-h)<0$ の時 $g^{*}$ は増加し, $f_{n}$ も増加する。一方, $H^{\prime}$ $(-h)>0$ の時 $g^{*}$ は減少し, $f_{n}$ も減少することがわかる。

Fig. 2 は，式(2)と式(4)で求められる $F_{m}$ に関して $h=$ $-30,30 \mathrm{~mm}, I=2.0 \mathrm{~A}$ の時の值をそれぞれ示した図であ る。本実験では-0.02 m< $x_{m}<0.02 \mathrm{~m}$ となるように加 振振幅を設定したため， $x_{m}$ の微小の仮定は成立し，式 (4)で定めた線形化は妥当であると言える。

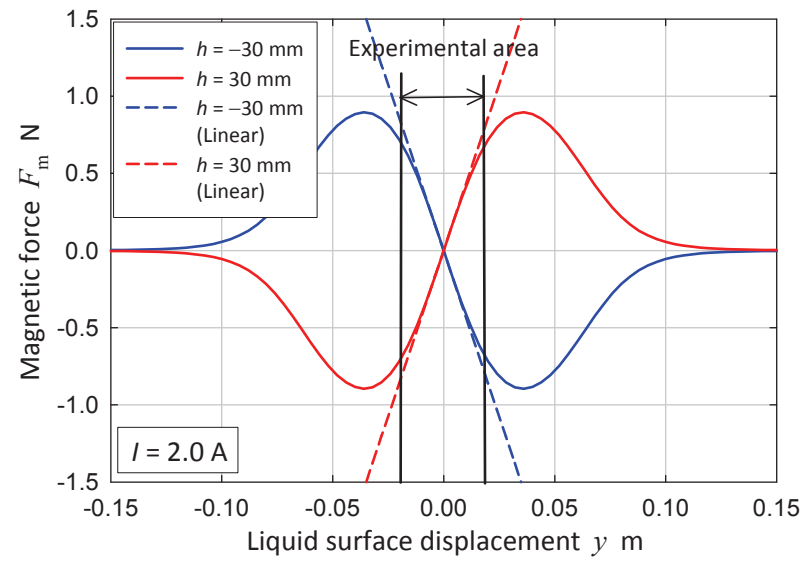

Fig. 2 Magnetic force acting on the liquid surface. 


\section{3 実験}

\section{1 一自由度強制振動実験方法}

実験装置の概略を Fig. 3 に示す。MF-TLCD は，U 字 管容器, 円形電磁石, 作動流体の磁性流体で構成され る。U 字管両側に設置された寸法の同じ電磁石に一定 の電流を供給することで定常磁場を印加し, 磁性流体 に磁気体積力が加えられる。

まず，加振器によって任意の加振振幅と周波数を持 つ正弦波をU 字管に与え, 液面振動が定常になるまで 待機する。そして，定常後の液面振動の波形をレーザ 一変位計によって測定することによって一自由度強制 振動時の液面振幅を得た。ここで，レーザー照射位置 によって液面振幅の值が少し異なることが確認された が，それによるばらつきは小さいため本実験では照射 位置が及ぼす振幅への影響は無視した。

加振振幅 $a_{0}=2.0 \mathrm{~mm}$, 電磁石位置 $h=-30,0,30 \mathrm{~mm}$, 供給電流 $I=0 \sim 2.0 \mathrm{~A}(0.25 \mathrm{~A}$ 刻み), 加振周波数 $f=0.5$ $\sim 1.8 \mathrm{~Hz}(0.02 \mathrm{~Hz}$ 刻み) として一自由度磁性流体液柱 の液面振幅周波数応答を測定した。ここで，共振周波 数付近では刻み幅を $0.01 \mathrm{~Hz}$ として細かく測定した。 また， $h$ は両電磁石で同じ值に設定し，対称磁場を磁 性流体に与えている。

使用磁性流体は Ferrotec 社のケロシンベース磁性流 体 MSGS60 とした。密度は $1327 \mathrm{~kg} / \mathrm{m}^{3}$ ，飽和磁化は $58.7 \mathrm{mT}$ である。本実験で使用した電磁石の中心軸上の 磁場分布を Fig. 4 に示す。



Fig. 3 Experimental apparatus.

\section{$3.2 \mathrm{U}$ 字管容器寸法}

本実験で使用した 3 種類のU 字管容器寸法図を Fig. 5 7 に示す。管内径は全て $40 \mathrm{~mm}$ であり，U字管の 水平方向の幅もほぼ全て同じになるように作製した。 これらU 字管の無磁場での液柱固有振動数 $f_{\mathrm{n}}$ は Fig. 5 ７で順番にそれぞれ 1.04, 0.95, $1.12 \mathrm{~Hz}$ である。

\section{4 結果}

\section{1 減衰比の定義と算出方法}

液面振幅周波数応答より算出を試みる減衰比引は以 下のように定義される無次元数である。

$$
\zeta=\frac{c_{m}}{c_{c}} \quad\left(c_{c}=2 m_{m} \omega_{m}\right)
$$

ここで， $c_{c}$ は磁性流体液柱の臨界減衰係数， $m_{m}$ は磁性 流体質量, $\omega_{m}$ は磁場印加後の液柱固有角振動数である。 ここで， $c_{c}$ はその系の減衰自由振動の挙動が振動する か否かの境界となる值を意味している。 $c_{c}$ は $\omega_{m}$ によっ て決まる值で, 磁場印加によって $\omega_{m}$ は変化することか ら， $c_{c}$ は磁場印加に伴って変化する。

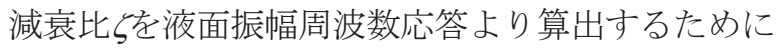
ハーフパワー法を用いた。これは，減衰が比較的小さ い場合の共振曲線のピークに着目して振動系の減衰を 求める方法である。共振点 $\omega$ の両側に共振点の最大振 幅のハーフパワー点（振幅では $1 / \sqrt{ } 2$ ）に等しい点を 取り，その二点の周波数をそれぞれ $\omega_{1}, \omega_{2}$ とした時らは 以下のように表される。

$$
\zeta=\frac{\omega_{2}-\omega_{1}}{\omega_{2}+\omega_{1}}
$$



Fig. 4 Distribution of magnetic flux density 


\section{2 液面振幅周波数応答}

従来型 U 字管に対して $h=-30,0,30 \mathrm{~mm}$ として，一 自由度強制振動実験を行った場合の無次元液面振幅 $a_{m} / a_{0}$ 周波数応答を Fig. $8 \sim 10$ に示す。なお， $a_{m}$ は磁 性流体液柱液面振幅を表す。レーザー変位計を用いて 液面振幅を測定することによって，共振点付近を含め て全体的に滑らかな応答曲線を得ることができた。し かし, $h=30 \mathrm{~mm}$ で磁場を強く与えると液面勾配が急 になり測定結果に少しばらつきが見られた。

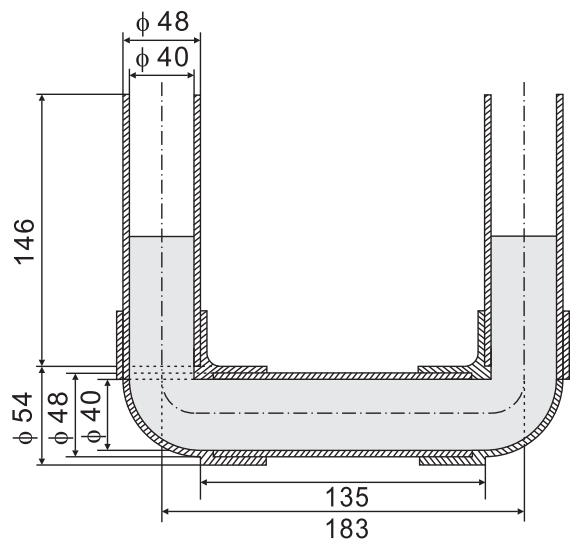

Fig. 5 The configuration of conventional U-pipe.

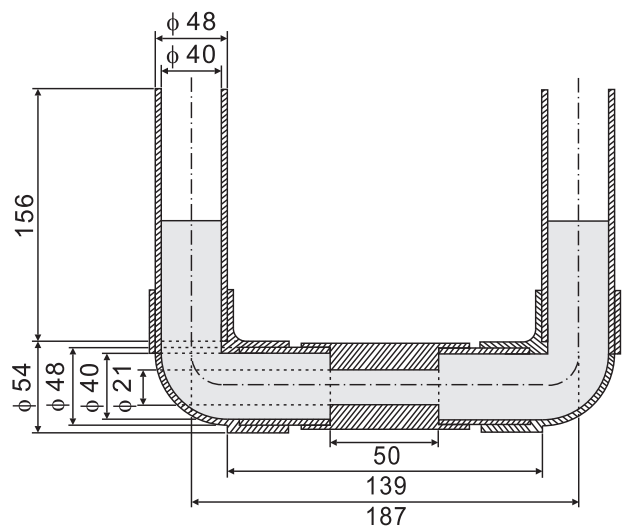

Fig. 6 The configuration of U-pipe equipped with orifice.

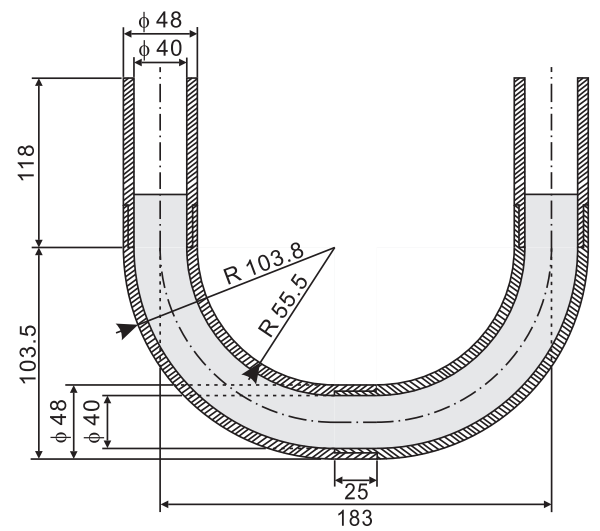

Fig. 7 The configuration of curved fluently U-pipe.
一自由度強制振動系では，周波数応答の極大值（共 振点）における加振周波数が液柱固有振動数と一致す る。実験結果を見てみると, $h=-30 \mathrm{~mm}$ の場合には電 流を大きくし磁場を強めることで共振点が右側へ推移 していることがわかる。つまり，この場合には液柱固 有振動数は増加している。逆に， $h=30 \mathrm{~mm}$ の場合に は磁場を強く与えるほど固有振動数は減少している。 また, $h=0 \mathrm{~mm}$ の場合，左右の液面に働く磁気体積力 が振動中に常に互いに打消しあうため，見かけ上は磁



Fig. 8 Frequency response of dimensionless liquid surface displacement when $h=-30 \mathrm{~mm}$.

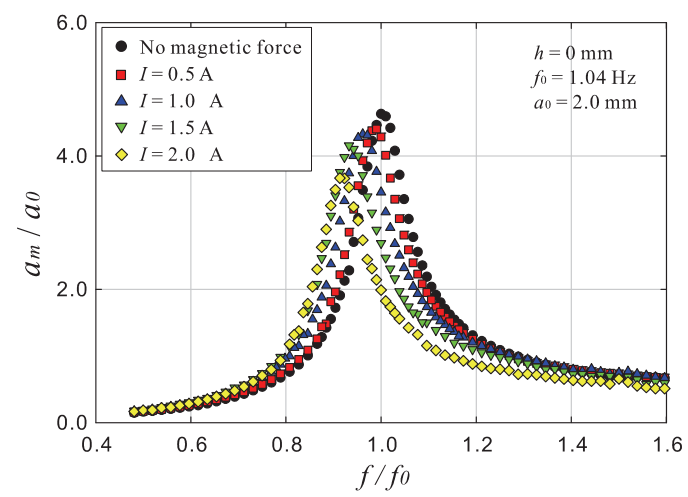

Fig. 9 Frequency response of dimensionless liquid surface displacement when $h=0 \mathrm{~mm}$.



Fig. 10 Frequency response of dimensionless liquid surface displacement when $h=30 \mathrm{~mm}$. 
性流体に力が加えられていない状態となる。しかし， Fig. 9 を見ると磁場を強くするにつれて少しずつでは あるが固有振動数が減少している。これは磁場印加に よる液面形状変化が原因であると考えられる。磁場印 加時, 液面は中心位置が下がるように勾配を作る。こ の傾向は磁場が強いほど顕著であり，これによって設 定した $h$ よりも少し大きな值を実際の $h$ は取ったため 固有振動数は減少したと考えられる。

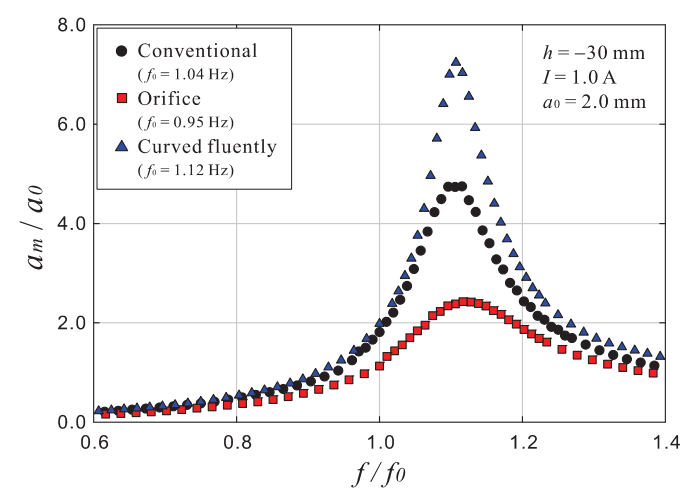

Fig. 11 Comparison of frequency response for three types of U-pipes when $h=-30 \mathrm{~mm}$.

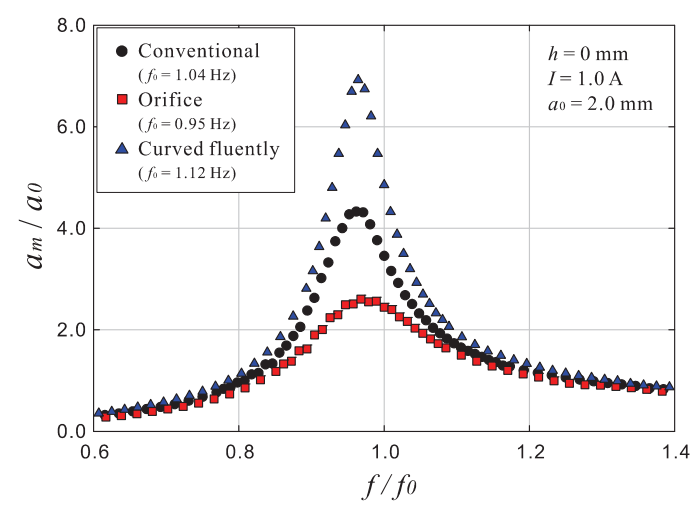

Fig. 12 Comparison of frequency response for three types of U-pipes when $h=0 \mathrm{~mm}$.



Fig. 13 Comparison of frequency response for three types of U-pipes when $h=30 \mathrm{~mm}$.

\section{3 共振点振幅の比較}

三種類の $\mathrm{U}$ 字管で液面振幅周波数応答を $h=-30,0,30$ mm の場合に比較した図をそれぞれ Fig. 11～13 に示す。 ここで,これらは電流 $I=1.0 \mathrm{~A}$ 与えた時の結果である。 また，実験の都合上，三種類の U 字管における無磁場 での液柱固有振動数 $f_{0}$ はそれぞれ少し異なっている。 そこで，共振点振幅を比較しやすく寸るため，今回は

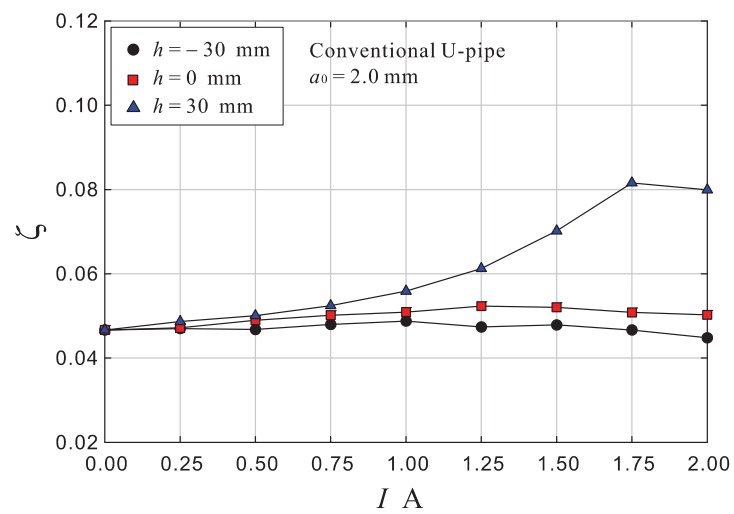

Fig. 14 Transition of damping coefficient $\zeta$ with increasing currency (conventional U-pipe).

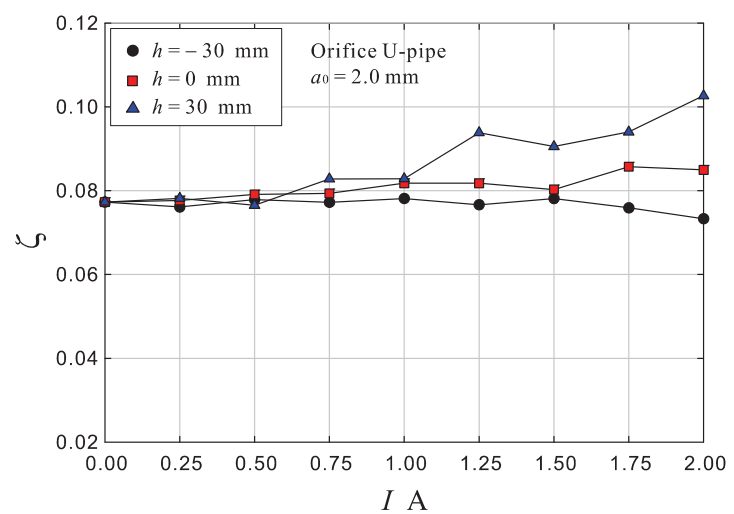

Fig. 15 Transition of damping coefficient $\zeta$ with increasing currency (U-pipe with an orifice).



Fig. 16 Transition of damping coefficient $\zeta$ with increasing currency (U-pipe curved fluently). 
加振周波数 $f$ U 字管それぞれの $f_{0}$ で無次元化した。

Fig. 11 13 を見ると，曲がり管が緩やかな U 字管で の共振点振幅が最も大きいことがわかる。これは，曲 がり管を緩やかにしたことで流体抵抗が減少し，減衰 力も減少したと考えられる。一方，オリフィスを付け たU字管で最も共振点振幅が小さくなったのは, オリ フィスによって流体抵抗が増加したからだと考えられ る。

\section{4 磁場と U 字管形状が減衰比に与える影響}

液面振幅周波数応答からハーフパワー法を用いて 減衰比を求め, U 字管形状毎にまとめた結果を Fig. 14 １6 に示す。まず，それぞれのU字管で無磁場での減 衰比を比較すると, 共振点振幅の大きさからも理解で きるように, 減衰比は曲がり管を緩やかにした U 字管 で最も小さくなる。一方，オリフィスを付けたU字管 では最も大きくなる。

次に, 磁場印加による減衰比の変化を見てみると, $h$ $=30 \mathrm{~mm}$ の場合のみ磁場を強めるにつれて減衰比が増 加していく傾向が見られた。これは全てのU字管形状 で見られる傾向である。 $h=-30,0 \mathrm{~mm}$ の場合には, 磁 場を印加しても減衰比には大きな影響は見られなかっ た。ただし， $h=-30 \mathrm{~mm}$ よりも $h=0 \mathrm{~mm}$ の場合の方 が減衰比は常に少し大きな值を取った。よって, $h$ を より大きくし, かつ磁場も強めてやることで減衰比を 更に大きくすることが可能だと考えられる。

このように, 液面振幅周波数応答から減衰比を定量 的に算出することができた。これらの值はU 字管形状 や磁場によって異なる值を取り, かつ電磁石位置によ ってもその傾向が異なることが確認されたため, 求め られた減衰比の值には一定の妥当性があると考える。

\section{5 液柱減衰力の変化が制振力に及ぼす影響}

減衰比が U 字管形状や磁場によって変化した場合, その変化が MF-TLCD の制振力へ及ぼす影響について 考察する。一般的に，パッシブダンパーが最も制振力 を発揮するのは固有振動数と外部からの加振振動数が 一致する時であり，その時の振幅だけ見れば減衰比が 小さい方が制振力は高いと言える。MF-TLCD は固有 振動数可変なセミアクティブダンパーであり, 加振振 動数との同調が可能である。よって，MF-TLCD にお いて減衰比はなるべく小さい方が制振力を高くするこ とができると考えられる。したがって，Fig. 7 のよう な曲がり管を緩やかにしたU字管を用いて, かつ $h=$
-30 mm とした場合が MF-TLCD を利用して制振を行 うには最適であると考えられる。

\section{5 結 言}

MF-TLCD で用いる U 字管形状として三種類の U 字 管を用意し, 一自由度磁性流体液柱強制振動実験を行 いハーフパワー法によって減衰比を求めた結果, 以下 の知見を得た。

1. U 字管形状に関係なく, 電磁石が静水面より下側 に設置された場合, 磁場強度増加に伴って減衰比 は変化しない. 一方, 電磁石が上側に設置された 場合, 磁場強度増加に伴って, 減衰比は増加する。

2. MF-TLCD では，曲がり管が緩やかな U 字管を用 いて，電磁石を静水面より下側に設置した時，最 適制振が可能となる。

(2015 年 4 月 17 日受付)

\section{参考文献}

[1] 渡邊, 減摇水槽の設計に就て, 造船協會會報, Vol. 46 (1930), pp. 125-153.

[2] 坂井, 高枝, 玉木, 液柱管ダンパー(Tuned Liquid Column Damper)の提案-液柱管の振動特性-, 土木学会構造工学論 文集，Vol. 35A (1989)，pp. 543-552.

[3] 木村, 阿部, 藤野, 可変オリフィスを利用したセミアク ティブ同調液柱管ダンパーの制御則, 構造工学論文集, Vol. 43A (1997), pp. 671-678.

[4] S. K. Yalla and A. Kareem, Semiactive tuned liquid column dampers: Experimental study, Journal of Structural Engineering, Vol. 129 (2003), pp. 960-971.

[5] J. Y. Wang, Y. Q. Ni, J. M. Ko and B. F. Spencer, Magneto-rheological tuned liquid column dampers (MRTLCDs) for vibration mitigation of tall buildings: modeling and analysis of open-loop control, Computers and Structures, Vol. 83 (2005), pp. 2023-2034.

[6] T. Oyamada, H. Masuda, K. Ikari and T. Sawada, Damping characteristics of a magnetic fluid tuned liquid column damper under static magnetic fields, International Journal of Applied Electromagnetics and Mechanics, Vol. 45 (2014), pp. 659-665.

[7] H. Masuda, T. Oyamada and T. Sawada, Experimental study on damping characteristics of the tuned liquid column damper with a magnetic fluid, Journal of Physics: Conference Series, Vol. 41 (2013), 012049 (9pp). 